\title{
Security Cooperation of Great Britain and West Germany in the Years 1979-1985
}

\author{
Współpraca Wielkiej Brytanii i Niemiec Zachodnich \\ w dziedzinie bezpieczeństwa w latach 1979-1985
}

\section{- Abstrakt •}

Artykuł opisuje główne kierunki i formy współpracy pomiędzy Wielką Brytanią a Niemcami Zachodnimi w zakresie polityki bezpieczeństwa w latach 1979-1985. Wybór takiej ramy czasowej podyktowany był ważnymi wydarzeniami na arenie międzynarodowej, które miały znaczący wpływ na ustanowienie doktryn militarno-politycznych i współpracy pomiędzy krajami zachodnimi, wśród których znajdowały się Wielka Brytania i Niemcy Zachodnie. Do wydarzeń tych należały inwazja sowiecka w Afganistanie (1979) oraz początek dostosowywania polityk i powstanie „nowego myślenia politycznego" w ZSRR (1985).

Słowa kluczowe: Niemcy, Wielka Brytania, NATO, Pakt Warszawski, Brytyjska Armia Renu, kwestia Niemiecka, Podwójna decyzja NATO z 12 grudnia 1979 r., Inicjatywa Obrony Strategicznej (SDI)

\section{- Abstract •}

The article considers the main directions and forms of cooperation between Great Britain and West Germany in the security policy in 1979-1985. Selecting the time frame of research is based on the important international events which had a significant influence on the formation of the military-political doctrines and cooperation between West countries, including the UK and West Germany. Such events included the Soviet invasion in Afghanistan (1979) and the beginning of the adjustment policies and the formation of a "new political thinking" in the USSR (1985).

Keywords: Germany, United Kingdom, NATO, Warsaw Pact, British Army of Rhine, the German question, NATO Double-Track Decision, Strategic Defense Initiative (SDI) 
UK course in world politics since 1979 featured a particularly close relationship with the United States and the so-called nationalism in relations with Europe. On 3 May 1979 Conservatives won election in the UK. Prime Minister Margaret Thatcher formed a new government. The neo-conservatives under the leadership of "Iron Lady" provided leadership of the country till November 1990, defining the main directions and priorities of domestic and foreign policy of Great Britain. In 1976, the head of the Conservative Party Margaret Thatcher outlined the basic principles of foreign policy in the party paper "The Right Approach". The main foreign policy goal of the Conservative program was to create a "strong Britain in a free world" (Minogue, Biddis, 1987). Neoconservatives called for a return to unrestricted free enterprise and values of the Victorian era, which gave impetus to the past greatness and prosperity of the UK. In the foreign policy of the state they are treated as a logical extension of domestic policy and the strategic goal of restoring lost Britain economic and political positions in Europe and the world. As the Foreign Office, Margaret Thatcher considered the European Communities and the United States as the two main pillars of British foreign policy. In relations with the USSR Cabinet of Margaret Thatcher took a more hard-line than the Government of E. Heath. This was caused mainly by Western countries disappointment in the results of the policy of detente (Deniskina, 1990).

The Social Democratic government of Germany from 1974 to 1982 was led by Chancellor Helmut Schmidt. The main objectives of the Federal Republic of Germany in Western Europe in the early 1980s were the further consolidation and deepening economic and political integration in the EC to ensure the impact of West Germany in Europe and the world. One of the important objectives of European integration was to find the most effective means and opportunities for opposition to socialism in the economy and in foreign policy. Detente in the 1970s caused many internal contradictions in the European Community, as its members had different attitudes towards the socialist countries. UK exercised restraint while West Germany was particularly interested in the active conduct of "eastern policy". West German magazine Der Spiegel initially praised Margaret Thatcher as a "difficult partner" to Germany (Salome der britischen Politik, 1979).

The first European government leader, whom Margaret Thatcher met as Prime Minister, was Helmut Schmidt. Helmut Schmidt's visit to London was planned by J. Callaghan Labour Government. Among conservatives there was disagreement on the need to invite the German Social-Democratic leader to the UK. Personally, Margaret Thatcher was in favor of a meeting with Mr. Schmidt, because she thought their views on international politics were similar so she sought to discuss with him a number of burning issues (Thatcher, The Downing Street Years, 1993). 
On 10 May 1979 Margaret Thatcher organized a dinner in honor of Mr. Schmidt at Downing Street. In her dinner speech, she named two major platforms of cooperation between the UK and West Germany: membership of the two countries in NATO and EC. "We have a common interest in achieving the military balance between East and West, because ... a balance will contribute to the establishment and preservation of peace and stability in Europe" - said M. Thatcher (Speech at Dinner for West German Chancellor Helmut Schmidt, 1979). Active discussion unfolded on cooperation in the military-political sphere. Schmidt said that the special position of Germany - the existence of the Federal Republic of Germany and the German Democratic Republic and the special status of Berlin - made Germans, more than any other people, sensitive to changes in East-West relations. Chancellor, as well as Margaret Thatcher, believed that in this area the aim was to achieve a military balance between NATO and the Warsaw Pact, in which you know that it would "be able to keep anyone who wants to attack you" (Vorsicht, sonst become ich Ärger in der Partei, 1979). During the visit of West German delegation in London were also held talks between Foreign Ministers of the two states - Peter Carrington and Hans-Dietrich Genscher. Following the meeting, the German press described Margaret Thatcher as a super-energetic, disciplined lady, who stayed cold and absolutely rational in the negotiations and had a strong belief in the successful implementation of her mission (Das Geheimnis der Mrs. Thatcher ist nicht ihr Wille, sondern ihre Glaube, 1979).

On 31 October 1979 in Bonn there was another meeting between Margaret Thatcher and Helmut Schmidt. The structure of the British delegation also included Minister of Foreign Affairs of Great Britain Peter Carrington, Minister of Finance George Howe, Minister of Defense Francis Pym and Agriculture Minister Peter Walker. An important place in the talks was devoted to issues of security and relations between the countries of East and West.

A new stage in the military-political cooperation of Great Britain and Germany, as well as the NATO countries in general, began in response to the Soviet invasion of Afghanistan in December 1979 and the change in the geopolitical situation in the Middle East. Since the beginning of the Soviet armed presence in Afghanistan, relations between the superpowers had deteriorated sharply. West Germany was the "best power at the NATO defense line", the most sensitive but also the most important in the strategic plan (Herr Schmidt in the Middle, 1981). Each step of the West German Chancellor could contribute to reducing tensions between East and West at the same time strengthening the security of the German nation divided by the "iron curtain". 
During the Anglo-West German summit consultations in 1980-1982 Chancellor Helmut Schmidt expressed full support for the NATO Double-Track decision of 12 December 1979 on the modernization of nuclear weapons. He assured Margaret Thatcher that if the Geneva talks with the Soviet Union on disarmament reach a deadlock, West Germany would dispose the NATO nuclear midrange weapons on its territory (Joint Press Conference with West German Chancellor Helmut Schmidt, 1981, 1982). Both countries called for closer cooperation with the United States (Arkhiv vneshney politiki Rossiyskoy Federatsii. - F. 757. Op. 25. - D. 43. - L. 81). According to the NATO Double-Track decision United States obtained the right to place on the territory of the Federal Republic of Germany and other Western European countries nuclear medium-range missiles ("Pershing-2" and cruise missiles). West Germany played a key role in the NATO decision. This fact was noted by West German scientists and publicists. Professor W. Albrecht wrote: "If Bonn said «no", such a decision would never be reached. It seems possible that "no" from England or some smaller countries - NATO partners - would not pose a threat to the decision to deploy missiles" (Novik, 1987). British Defense Minister Francis Pym during a visit to West Berlin on 25 February 1980 called the modernization of NATO's nuclear forces in Western Europe, including the British territory, part of the "unlimited UK debt" in the protection of Berlin (Kohl Points Europe to Political Union, 1984). He did not exclude even the possibility of the German control over the use of "Pershing-2" and cruise missiles on West German territory (Arkhiv vneshney politiki Rossiyskoy Federatsii. F. 69. - Op. 71. - P. 279. - D. 14. - L. 51). In view of developments in Afghanistan Francis Pim considered his visit symbolic, seeing that the discharge can be carried out only from the standpoint of safety and security (Spitzer, 1980).

According to the British government, Helmut Schmidt, after the adoption of the NATO Double-Track decision and the Western countries preparation for placement of American medium-range missiles in Europe, was to act as a mediator between East and West. On the one hand, the German Chancellor would try to convince the Kremlin that it was the actions of the USSR that had led to the fact that the East-West relations were at such a low level. On the other hand, Helmut Schmidt could help soften the US position towards the USSR. All this, of course, would be consistent with the interests of the divided German nation. In the Anglo-West German negotiations in 1980 and 1981 understanding between Margaret Thatcher and Helmut Schmidt on international politics and security was getting only deeper.

By the early 1980s Germany had turned into the most powerful NATO member in Europe. Relationship between West Germany, which was on the front line 
of the conflict between East and West, and the United Kingdom with its security policy in the nuclear age was gradually strengthened. "Pacific Union" of Britain and West Germany which was formed in 1970-1980s represented a kind of partnership between the two countries within the NATO alliance. It was built on the solid foundation of their common interests. There were four common problems of Germany and the United Kingdom in the field of security in this period: maintaining a close alliance with the United States; development of military-political cooperation with Europe; the creation of independent European nuclear force and the maintenance of stable relations with the USSR (Rohe, 1992). West German Army on the quantitative composition was in the early 1980s on the first position in Western Europe, well ahead of France and the UK (Shtayngaus, 1981). The number of armed forces of the Bundeswehr in the 1979 reached 495 thousand, while in the UK the figure was 323 thousand (Shmidt, 1982). West Germany was behind Britain only in the naval forces.

British government adheres to NATO's decision on the annual increase in military spending of member countries by $3 \%$. After the election in 1979 in the Labour Party intensified leftist tendencies, one of the manifestations of this was the requirement for unilateral nuclear disarmament. Under these conditions, important for the Conservatives became not only the implementation of military programs, but also their competent political support. In 1980 the British government decided to order from the United States "Trident" -nuclear missile system - and to build a new nuclear submarine. However, the overall economic situation in the country did not allow to increase military spending significantly. The UK representatives discussed the plans of "Trident" system purchase with a German general Tandetski who expressed an overall positive attitude of German military circles to the UK plans, but added: "We are afraid that if we talk too much about it, you want us to help to pay for it" (Goertemaker, 2006). United Kingdom was objectively in need of West German financial assistance for the implementation of major military projects. British government was sometimes inclined to present the British Army modernization as a measure aimed at maintaining peace and security in Europe, primarily on the territory of Germany. Therefore, the British government considered reasonable and fair any financial support of the British armed forces from West Germany which at that time was the most powerful economy in Western Europe and had the greatest potential for the development of new technologies.

Deepening the UK-West Germany cooperation in the military-political sphere became natural also because of the placement of the British Army of the Rhine on the German territory. In the federal states of Lower Saxony and North RhineWestphalia were placed 55 $5^{\text {th }}$ British Army troops and 11 thousand servicemen of 
the Royal Air Forces (RAF). Together they formed the British Army of Rhine (BAOR). In $198175 \%$ of British combat aircraft were in the UK, the remaining $25 \%$ - on the territory of the Federal Republic of Germany. They were part of the 12 squadrons: four squadrons "Jaguars", two "Buccaneer", "Phantoms" and "Harrier". In an interview with the German newspaper Die Welt on 19 March 1980 Margaret Thatcher said: "If Germany is in danger, then we are in danger too. Therefore, we guarantee freedom of Berlin. Germany and Britain are very closely related" (Barzel, 1980).

In 1982 there was a cooling of Anglo-West German relations because of the Falklands War. At the beginning of the campaign West Germany took the side of Great Britain and joined the Common Market sanctions against Argentina. However, after passing the British navy for active combat operations there were some criticisms of the United Kingdom foreign policy coming from Bonn. Germany made an active effect on the British government on the cessation of operations in the Falklands. The sympathies of the Federal Republic of Germany to the UK as a "victim of aggression" by the end of the campaign came to naught (Arkhiv vneshney politiki Rossiyskoy Federatsii. - F. 757. - Op. 27. - P. 155. - D. 38. L. 86). After the end of the Falklands War, the relationship between Great Britain and West Germany were leveled and continued to develop in the framework of NATO. On 10 June 1982 at a meeting of NATO leaders in Bonn Margaret Thatcher expressed the need to extend the range of NATO's interests and responsibilities around the world. However, most countries in Western Europe cautiously reacted to this proposal for fear of being drawn into an armed conflict for the interests of the USA (Arkhiv vneshney politiki Rossiyskoy Federatsii. - F. 69. - Op. 74. - P. 286. - D. 14. - L. 103).

On 1 October 1982 CDU leader Helmut Kohl was elected as the new Chancellor of West Germany. In domestic approaches to the development of their countries Margaret Thatcher and Helmut Kohl had a lot in common, but between them there were often disagreements on foreign policy. On 19 October 1982 first formal talks between Margaret Thatcher and Helmut Kohl were held in London. The British Prime Minister called the negotiations a meeting of common points of view. Margaret Thatcher attached great importance to membership of the United Kingdom and Germany in NATO. She was sure that any problems between members of the alliance are negligible in comparison with their overall goals and objectives in the modern world. Helmut Kohl agreed with this, adding that NATO was an Atlantic bridge between Europe and the United States.

During a bilateral meeting in Bonn on 28-29 October 1982 security issues were also discussed. At a press conference following the Anglo-West meeting Hel- 
mut Kohl noted that the relationships between the UK and West Germany "are built on a solid and reliable basis of the common interests of both countries in the European Community and NATO" (Joint Press Conference with West German Chancellor Helmut Kohl, 1982). Chancellor of Germany regarded the UK as a guarantor of security, stressing that "the British Army of Rhine helps to maintain freedom in the country, besides the United Kingdom is one of the four Berlin's powers" (Joint Press Conference with West German Chancellor Helmut Kohl, 1982). He noted that the British and West German leadership are going to continue to intensify the interaction between BAOR and the Bundeswehr.

On 23 April 1983 Helmut Kohl and Margaret Thatcher endorsed the NATO Double-Track decision. On 13 December 1983 came into force an agreement between the UK and West Germany, according to which the British armed forces stationed on the territory of the Federal Republic of Germany were to be brought into action in times of crisis or war. Germany, for its part, has committed to provide civilian aid for British troops and civilians of Great Britain during the war or crisis (Great Britain. Treaty Series, 1984).

Since 1982 there had been an obvious increase in the range of military-political cooperation between the UK and West Germany. After the Soviet invasion in Afghanistan and the adoption of NATO Double-Track decision defense spending in Western countries increased considerably. In the UK in the 1982/1983 fiscal year, it increased by $16.7 \%$ compared to the $1978 / 1979$ financial year. In the same period, it accounted for $5 \%$ of the gross national product. According to this indicator, Britain went ahead of France, Italy and West Germany, where the economic situation at that time was better than in the UK (Baranovskiy, 1988).

Relationship between Great Britain and West Germany in the military-political sphere was subjected to the test in November 1983 in connection with the US intervention in Grenada. At a meeting on 9-10 November 1983 in Bonn, the leaders of both countries assured the international community that Grenada had not spoiled relations within NATO. Margaret Thatcher and Helmut Kohl once again confirmed their solidarity with US policy (Arkhiv vneshney politiki Rossiyskoy Federatsii. F. 162. - Op. 60. - P. 363. - D. 5. - L. 10). At a joint Anglo-West German Conference on 9 November 1983 Helmut Kohl said: "Together with the British Prime Minister we shared belief that the NATO alliance as a part of the United States, Canada and Western Europe was in no way split by what had happened in Grenada ... now it is important to emphasize once again our friendship with the United States" (Joint Press Conference with West German Chancellor Helmut Kohl, 1983).

The United Kingdom continued to support West Germany in an effort to implement the NATO Double-Track decision and to place on the territory of the 
West Germany American medium-range missiles "Pershing-2" and cruise missiles. In December 1982 Yuri Andropov proposed to reduce the number of rockets "SS-20" from 243 to 150 , to destroy a part of warheads aimed at the West, and to push the rest beyond the Urals. For this the Soviet Union offered West Germany to abandon the implementation of NATO Double-Track decision. West German Foreign Minister Hans-Dietrich Genscher supported the Soviet leader, but Helmut Kohl insisted on the termination of negotiations, although some government ministers considered beneficial compromise with the Soviet Union (PM lashes at "fickle fears", 1983). On 22 November 1983 the Bundestag of West Germany by the majority of votes approved the NATO decision on the deployment in Germany of new American medium-range missiles. The Soviet Union through negotiations in Geneva tried to change the decision of West Germany, but in the end "Pershing-2" were placed at the US base "Heise".

West Germany was also at the center of NATO's strategic plans for Europe. The USA placed in Western Europe 464 "Tomahawk" cruise missiles. It was a fundamentally new low-level weapon (up to 50-60 m) that was able to penetrate the air defense system and to strike targets at a distance of $2600 \mathrm{~km}$ with a high accuracy. 160 such missiles were placed in the UK, 112 - in Italy, 96 - in West Germany, and 48 in the Netherlands and Belgium (Novik, 1987). In 1984 the German military expenditure per capita amounted to \$237 in the UK - \$ 416 (Baranovskiy, 1988). As a result, by 1985 the share of the Bundeswehr accounted for $100 \%$ NATO air control in Europe, $70 \%$ of NATO's Navy in the Baltic Sea, $50 \%$ of ground forces unit (Fyodorov, 1984). Although West Germany took only $1 \%$ of the entire territory of the member-states of NATO, it contained $17 \%$ of the armed forces of this organization. As the amount of military spending, West Germany was on the third position in NATO after the US and Britain (Khirillov, 1986). Its military budget had increased over the years 1983-1986, from 46.8 million marks to 50 billion marks (Novik, 1987). By the mid-1980s on the territory of the Federal Republic of Germany were located the largest stocks of US nuclear weapons and chemical weapons in Western Europe. Former Minister of State in the German Foreign Ministry A. Mertes said in 1985 that "the United States are well aware of the fact that the Western alliance without a foundation solid and trust-based cooperation between Washington and Bonn cannot exist". At this time in the UK there were 29 thousand US troops and 400 combat aircraft. According to official data of the Ministry of Defense, in April 1983 on its territory was placed 75 American bases and installations (Khirillov, 1986).

By 1985, Kohl would not accept the role of the UK as a mediator between West Germany and the USA. West Germany by that time had turned into an 
economic giant and become de facto the main partner of the US in Europe, as the most powerful member of NATO and European Community. The government of West Germany was the first among US allies to support American plans for "Star Wars". Helmut Kohl, in his speech on 18 April 1985 outlined the program of the Strategic Defense Initiative (SDI) as "justified and politically necessary in the West security interests" (Khirillov, 1986). In 1984-1985 active supporters of Germany's participation in the American space program were the Minister of SDI research H. Rizenhuber and Chief of Staff at the German Foreign Ministry Planning K. Seitz (Pavlov, 1989). Two of the Bundestag committee on special hearings on the issue of the SDI in December 1985 by the number 8 out of 11 voted against its deployment.

Conservative UK government had already signed an intergovernmental agreement with the United States on economic, legal and technical cooperation between the countries in the development of the SDI program. In February 1985 Margaret Thatcher made it clear to the US Congress that Britain wanted to participate directly in the SDI project, although the involvement of Western Europe in the project, according to the British Prime Minister, made the European countries even more dependent on scientific and economic development of the USA (Can Europe and Germany Grow Up?, 1985). Unlike Margaret Thatcher, the Foreign Office reacted with restraint to SDI. Diplomats feared that the "Star Wars" program would spread to outer space arms race and undermine the possibilities of improving East-West relations. British Foreign Office believed that SDI would not bring any benefits to the UK foreign policy.

In the mid-1980s Great Britain could not afford the implementation of major military projects alone. Long-term problems with the EEC, which required enormous resources for resolving, negatively affected the military capabilities of England. Margaret Thatcher planned to purchase from the US of a new nuclear program "Trident-2", but the former foreign minister David Owen had publicly stated that "England cannot afford it. A small UK has no future" (Kriesengespräch in London, 1980). It became obvious that for the implementation of major defense projects the UK needs an ally in Europe. West Germany, with its economic potential and dedication to NATO looked the most attractive for British leadership. On 18 January 1985 at a meeting with Helmut Kohl in Bonn Margaret Thatcher was in favor of the possible participation of the Bundeswehr in military operations of the United Nations, as well as for the participation of West German capital in the development of the Euro-tank and the Euro-fighter projects (Gatermann, 1985).

Chancellor Helmut Kohl attached great importance to the location of the British Army of the Rhine on the territory of the Federal Republic of Germany, rank- 
ing it as the UK contribution to the maintenance of security on the West German territory. On 20 September 1983 Margaret Thatcher first visited the British Army of Rhine as a Prime Minister. During the meeting she was "delighted in the morale of the armed forces, their professionalism ... organization and cooperation with the Germans" (Joint Press Conference with West German Chancellor Helmut Kohl, 1983). However she politely declined the flight in a fighter plane "Harrier", which was in the BAOR arms, as, according to her point of view, the "Harrier" was unlikely to enjoy such a pilot. During the Anglo-West German meeting on 27 November 1985 Margaret Thatcher and Helmut Kohl agreed on a joint visit to the BAOR in 1986. German Chancellor publicly stated the desire of West Germans to deepen contacts between the English and the German armed forces for the protection of "our common freedom" (Joint Press Conference with West German Chancellor Helmut Kohl, 1985). According to Margaret Thatcher, visiting the BAOR was to demonstrate the solidarity of both countries in the framework of cooperation in NATO, as well as a general commitment of the UK and West Germany to the idea of free Europe.

However, Margaret Thatcher stayed rather cold to the desire of Helmut Kohl to establish contacts with the socialist countries, including the GDR. The UK policy on the German question was to prevent the inclusion of the whole Germany in the Soviet sphere of influence. PM was frightened by the prospect of a speedy political unification of Europe, which Germany stepped up with a constant reference to the unification of Germany. Margaret Thatcher believed that the very geographical position of the German nation made it strategically important. United Germany, in her opinion, would be the most destabilizing force on the continent, if it was not closely tied to NATO. At the same time, Britain tried to enlist the support of France on the German question. At a dinner party on the basis of the Franco-British talks on 30 November 1984 Margaret Thatcher recalled that 66 thousand British troops were in West Germany and 50 thousand French servicemen guard the Franco-German border. "We both have a story, which gives us a common interest and a shared responsibility" - the British Prime Minister hinted (Thatcher, 1987).

In 1985 in connection with the election to the post of General Secretary of the CPSU Mikhail Gorbachev a new approach in the relations between East and West began to form. The Soviet leadership decided to abandon the foreign policy of the "Brezhnev Doctrine" - a possible military intervention in the internal affairs of the socialist countries - and made it clear for the socialist states that in a crisis they would have to solve their internal problems on their own. Since the mid-1980s there was a gradual improvement of relations between the USSR and 
the West countries, which later was reflected in a change in the forms and methods of cooperation between Great Britain and Germany in the military-political sphere.

\section{References:}

Salome der britischen Politik. (1979). Der Spiegel, p. 118.

Speech at Dinner for West German Chancellor Helmut Schmidt. (1979). Derived from: www.margaretthatcher.org/document/104080.

Kriesengespräch in London. (1980). Die Welt, p. 1-2.

Herr Schmidt in the middle. (1981, November 23). The Times, p. 9.

Joint Press Conference with West German Chancellor Helmut Schmidt. (1981). Derived from: www.margaretthatcher.org/document/104646.

Joint Press Conference with West German Chancellor Helmut Kohl. (1982). Derived from: www.margaretthatcher.org/document/109421

Joint Press Conference with West German Chancellor Helmut Schmidt. (1982). Derived from: www.margaretthatcher.org/document/104898.

Joint Press Conference with West German Chancellor Helmut Kohl. (1983). Derived from: www.margaretthatcher.org/document/105437.

Joint Press Conference with West German Chancellor Helmut Kohl. (1983). Derived from: www.margaretthather.org/document/105467.

PM Lashes at "Fickle Fears". (1983). The Sunday Times, p. 1.

Great Britain. Treaty Series. (1984). Agreement Between the Government of the UK and the Government of the FRG. London: HMSO.

Kohl Points Europe to Political Union. (1984). The Times, p. 5.

Can Europe and Germany Grow Up?. (1985). The Guardain, p. 15.

Joint Press Conference with West German Chancellor Helmut Kohl. (1985). Derived from: www.margaretthatcher.org/document/106183.

Barzel, R. (1980). Thatcher: wer Deutschland bedroht, bedroht auch uns. Die Welt, p. 1.

Gatermann, R. (1985). London wünscht Einsatz Bonns in Kriesengebieten. Die Welt, p. 6.

Goertemaker, M. (ed.). (2006). Britain and Germany in the XXth Century. Oxford.

Minogue, K., Biddis, M. (eds.). (1987). Thatcherism: Personality and Politics. New York: St Martin's Press.

Rohe, K. (ed.). (1992). Deutschland-Grossbritanien - Europa: Politishe Traditionen, Partnerschaft und Rivalität. Bochum.

Spitzer, G. (1980). Britain Gives Berliners Word of Assurance. The Times, p. 5.

Thatcher, M. (1987). In Defence of Freedom. New York: Prometheus.

Thatcher, M. (1993). The Downing Street Years. New York: Harper Collins Publishers.

Wirth, F. (1979). Das Geheimnis der Mrs. Thatcher ist nicht ihr Wille, sondern ihre Glaube. Die Welt, p. 8.

Wirth, F. (1979). Schmidt: Vorsicht, sonst become ich Ärger in der Partei. Die Welt, p. 1.

Wirth, F. (1985). Britain in Europe. Die Welt, p. 1. 
Arkhiv vneshney politiki Rossiyskoy Federatsii. - F. 162. - Op. 60. - P. 363. - D. 5. - L. 10. Arkhiv vneshney politiki Rossiyskoy Federatsii. - F. 69. - Op. 71. - P. 279. - D. 14. - L. 51. Arkhiv vneshney politiki Rossiyskoy Federatsii. - F. 69. - Op. 74. - P. 286. - D. 14. - L. 103. Arkhiv vneshney politiki Rossiyskoy Federatsii. - F. 757. - Op. 25. - D. 43. - L. 81.

Arkhiv vneshney politiki Rossiyskoy Federatsii. - F. 757. - Op. 27. - P. 155. - D. 38. - L. 86. Baranovskiy, V. (1988). Zapadnaya Evropa: voyenno-politicheskaya integraciya. Moskva: Mezhdunarodnyje otnosheniya.

Deniskina, V. (1990). Politicheskij portret M. Thatcher: Nauchno-analiticheskij obzor. Moskva: Inion an USSR.

Khirillov, G. (1986). Bonn: Mirolyubivaya ritorika i militaristskaya prakhtika. Mezhdunarodnaya zhizn, 3, 59-68.

Novik, F. (1987). SSSR-FRG: problemy sosushchestvovaniya i sotrudnichestva (1976-1985 22.). Moskva: Nauka.

Pavlov, N. (1989). Vneshnyaya politika FRG: kontseptsii i realii 80-h godov. Moskva: Mezhdunarodnye otnosheniya.

Fyodorov, V. (1984). V farvatere Vashingtona. Mirovaya ekonomika i mezhdunarodnye otnosheniya, 1, 78-81.

Shmidt, M. (1982). FRG v sovremennom mire. Mirovaya ekonomika i mezhdunarodnye otnosheniya, 4, 41-53.

Shtayngaus, K. (1981). Vozrozhdeniye velikhoy derzhavy? Moskva: Mezhdunarodnye otnosheniya. 